\title{
The role of the insulin-like growth factor-1 system in breast cancer
}

\author{
Panagiotis F Christopoulos ${ }^{1 *}$, Pavlos Msaouel $^{2}$ and Michael Koutsilieris ${ }^{1}$
}

\begin{abstract}
IGF-1 is a potent mitogen of major importance in the mammary gland. IGF-1 binding to the cognate receptor, IGF-1R, triggers a signaling cascade leading to proliferative and anti-apoptotic events. Although many of the relevant molecular pathways and intracellular cascades remain to be elucidated, a growing body of evidence points to the important role of the IGF-1 system in breast cancer development, progression and metastasis. IGF-1 is a point of convergence for major signaling pathways implicated in breast cancer growth. In this review, we provide an overview and concise update on the function and regulation of IGF-1 as well as the role it plays in breast malignancies.
\end{abstract}

Keywords: Insulin-like growth factor-1 (IGF-1), IGF-1 receptor (IGF-1R), IGF-binding proteins (IGFBPs), IGF-1 signaling, IGF-1 regulation, Estrogens, Estrogen receptor (ER), Breast cancer, Mammary tumorigenesis

\section{Introduction}

The Insulin Like Growth Factor 1 (IGF-1) system which includes IGF-1, IGF-binding proteins (IGFBPs) and the IGF-1 receptor (IGF-1R), plays a significant role in human physiology, particularly in the development and function of many tissues, including the mammary gland. IGF-1 is a key mediator of mammary terminal end bud and ductal formation during development [1]. Experimental findings have demonstrated that normal rat mammary epithelial cells continue to proliferate in serum-free media in response to IGF-1, suggesting that the IGF-1 system plays an important role in mammary gland function and maintenance [2]. In contrast, over the last two decades many studies have implicated the IGF-1 system in the development of several malignancies including breast cancer. Indeed, breast tumors may aberrantly express each component of the IGF- 1 system. To date, an increasing number of studies have attempted to elucidate the molecular mechanisms underlying the association of the IGF-1 system with breast malignancy [3-5].

\section{The IGF-1 system in breast cancer}

IGF-1 is a $7.7 \mathrm{kDa}$ single-chain polypeptide encoded by chromosome 12. The 70 amino acid IGF-1 protein

\footnotetext{
* Correspondence: panutsoschr@hotmail.com

'Department of Experimental Physiology, Medical School, National and Kapodistrian University of Athens, 75 Mikras Asias Street, 11527 Goudi, Athens, Greece

Full list of author information is available at the end of the article
}

consists of four domains [6] and is produced primarily in the liver under the direct stimulation of Growth Hormone (GH). IGF-1 gene expression is controlled by both transcriptional and post-translational modifications. Distinct IGF-1-peptides may arise via the utilization of different promoters, alternative splicing, proteolytic processing and glycosylation events [7]. IGF-1 is expressed in almost every human tissue. In both normal mammary gland and malignant breast tissues, IGF-1 is mainly expressed by stromal and only rarely by epithelial cells [8]. Circulating IGF-1 levels vary depending on the person's age: there is initially an increase in serum IGF-1 from birth to puberty, followed by a stable decline with age in response to the lower GH levels $[9,10]$. The mitogenic, anti-apoptotic and other effects of IGF-1 protein are mainly mediated by the transmembrane tyrosine kinase receptor IGF-1R, which in contrast to IGF-1, is mainly expressed in the mammary epithelium. Tetrameric IGF-1R consists of two $\alpha$-identical and two $\beta$-identical subunits. Ligand binding and subsequent phosphorylation of IGF-1R triggers the activation of two major signaling cascades via the insulin receptor substrate 1 (IRS-1): the phosphatidylinositol 3-kinase/AKT kinase (PI3K/AKT) pathway and the RAF kinase/mitogen activated protein kinase (RAF/MAPK) pathway which stimulate proliferation and protection from apoptosis [11]. Notably, the IRS-1 has been found to be overexpressed in primary breast tumors [12]. The bioavailability and half-life of 
circulating IGF-1 is regulated by a family of six IGFbinding proteins (IGFBP1-6) [13]. Each IGFBP can bind to IGF-1 with high affinity and is regulated by several specific IGBPB proteases. Approximately $1 \%$ of circulating IGF-1 remains unbound, while the rest is mainly bound to IGFBP3, forming a complex with an acid-labile subunit [14].

Breast Cancer $(\mathrm{BrCa})$ remains one of the leading causes of cancer-related death worldwide. The heterogeneity and variability in treatment and survival response, underscore the need to elucidate the biological mechanisms driving $\mathrm{BrCa}$. A proposed molecular profile approach for breast tumor classification defines distinct molecular subtypes of the disease based on differences in the expression patterns of estrogen receptor (ER), progesterone receptor (PR) and HER2 (ERBB2) [15]. Although BrCa has been intensely studied and multiple reported biomarkers and molecular targets have been reported in the literature, only a few are of proven relevance to routine clinical practice. Both in vitro and in vivo models, as well as clinical and epidemiological data have indicated the role of the IGF-1 system in $\mathrm{BrCa}$ via many diverse endocrine, paracrine and autocrine signaling pathways $[16,17]$. Although some of these findings are conflicting, many components of the IGF-1 system are known to be altered during $\mathrm{BrCa}$ establishment and progression $[9,16,18]$.

Circulating IGF-1 levels and breast cancer (endocrine role) Since the initial report by Peyrat et al. [19], many epidemiological and prospective studies have attempted to confirm the positive correlation between plasma IGF-1 levels and BrCa risk. A pooled data analysis of seventeen prospective studies from twelve countries by the Endogenous Hormones and Breast Cancer Collaborative Group showed a clear association between circulating IGF-1 and BrCa risk in Estrogen Receptor positive (ER $\left.{ }^{+}\right)$ tumors independent of IGFBP3 and menopausal status [20]. This finding is also supported by the data analysis from the European Prospective Investigation into Cancer and Nutrition cohort [21]. Serum IGF-1 levels have also been positively associated with increased disease risk among BRCA gene mutation carriers (hereditary $\mathrm{BrCa}$ ) in an Italian cohort study [22]. In contrast no correlation was found between IGF-1 levels and breast cancer development in a cohort of Brazilian women [23] or women during early pregnancy [24]. Mammographic density is one of the strongest predictors of breast cancer development and may be associated with serum IGF-1 levels in premenopausal women. Dorio et al., found an association between mammographic density and serum IGF-1 in premenopausal women [25] though recent studies did not corroborate this finding [26,27].
The association of IGF-1 with disease prognosis following tumor establishment is also currently under investigation. High circulating IGF-1 levels have been positively correlated with bad prognosis in patients undergoing endocrine therapy [28], while another study found that high serum IGF-1 is associated with increased all-cause mortality in a cohort of women with established breast malignancy [29]. Further studies measuring both mRNA and protein levels are warranted, in order to better delineate the role of circulating IGF-1 in disease risk and progression.

\section{IGF-1 polymorphisms in breast cancer}

Over the last decade, there has been increasing interest in the studying of the genomic analysis of the IGF-1 gene for specific alterations involved in cancer formation and progression. One of the most studied genetic variations of $I G F-1$ is a polymorphic sequence of repeating cytosine-adenine dinucleotides $(\mathrm{CA})$ ranging from 10 to 24 repeats in length, with the $\mathrm{CA}_{19}$ being the most common allele. This repeating sequence is located almost $1 \mathrm{~kb}$ upstream of the transcription initiation site and is thus considered to be a promoter polymorphism likely implicated in regulating IGF-1 protein levels. No significant association has been found between $\mathrm{CA}_{19}$ and $\mathrm{BrCa}$ risk among Arab Omani women in both post- and premenopausal status [30]. In contrast, in another case control study among African-American and Hispanic women, a significant correlation between the non-19/ non-19 allele polymorphisms and breast cancer was detected, predominantly in premenopausal women [31]. No association between CA 17, 19 and 20 alleles and breast cancer risk was found in a meta-analysis by Huang et al. [32], whereas a more recent meta-analysis of 11 studies by He et al. reported that CA 19/19 may confer a decreased risk for BrCa development in Caucasian but not in Asian women [33]. Indeed, there is growing evidence that the $\mathrm{CA}_{19}$ allele is associated with increased incidence of breast and other cancers in Asians [34]. Allelic length has also been found to correlate with disease development. BrCa risk is increased in Iranian women carrying two alleles of CA longer than 19 and decreased in those carrying two alleles shorter than 20 [35]. Other genetic variations including single nucleotide polymorphisms (SNP's) and SNP combinations (haplotypes) have been studied for potential associations with $\mathrm{BrCa}$. Most of the SNPs studied are in areas located in highly evolutionary conserved regions (ECR) near to the transcription factor binding domains (BD), thereby affecting transcription regulation. Biong et al. reported an association between a common IGF-1 genetic haplotype, plasma IGF-1 levels and mammographic density in postmenopausal Norwegian women [36] while neither a single SNP, nor any diplotype (combination of two haplotypes) was associated 
with circulating IGF-1 levels in a multivariate analysis of Swedish women. In the same study, a rare diplotype variant found in a small proportion of women $(n=14 / 325)$ strongly correlated with development of early-onset $\mathrm{BrCa}$ [37]. Another individual SNP (rs 7965399), located in the 5 '-unstranslated region of IGF-1 gene, near the transcription initiation site, has been associated with $\mathrm{BrCa}$ risk in a recessive model, particularly in estrogen receptor negative $\left(E R^{-}\right)$or early menopause Chinese women [38]. The Breast and Prostate Cohort Consortium (BPC3), a collaboration of large US and European Cohorts, genotyped a total of 1416 SNP's for 24 genes involved in the IGF-1 pathway in 6,292 Caucasian postmenopausal women with diagnosed $\mathrm{BrCa}$ as compared to 8,135 controls and did not find any SNP associations with $\mathrm{BrCa}$ risk [39]. In addition other large collaborative studies using data from the BPC3, genotyped a total of 302 SNPs in a sample size of more than 5,500 Caucasian women and detected a clear association between genetic variations of IGF-1 and plasma IGF-1 levels but no association with $\mathrm{BrCa}$ risk [40]. Despite the large number of studies identifying IGF-1 gene polymorphisms in association with $\mathrm{BrCa}$ risk, only a few have investigated the relationship of such polymorphisms with disease progression. Homozygotes for the non-19/non-19 CA allele with non metastatic $\mathrm{BrCa}$ have been found to have favorable prognostic factors and longer disease-free and overall survival [41], while HER2+ patients carrying the rare SNP rs2946834 allele have poorer prognosis and decreased event-free survival probably due to increased IGF-1 circulating levels [42]. Very recently, a meta-analysis of Genome-Wide Association studies (GWAS) found that the SNP rs703556, located $222 \mathrm{~kb}$ upstream of IGF-1 gene, correlates with mammographic density [43]. The importance of this finding is highlighted by the fact that GWAS utilizes a less "biased" approach by first detecting, among a large pool of candidate SNPs, those SNPs that strongly correlate with disease risk or progression. GWAS then determine if these SNPs are located near to the IGF-1 gene. This is in contrast to other studies described above, which use genetic variants of IGF-1 as candidate risk factors.

\section{Autocrine and paracrine role of IGF-1 in breast cancer}

In contrast to the serum IGF-1 expression findings described above, increased IGF-1 mRNA levels within tissue samples may confer a favorable outcome and have been associated with increased disease-free survival (DFS) in patients with diagnosed estrogen receptor positive $\left(E R^{+}\right)$breast cancer [44]. This finding was further supported by microarray analysis of tumor samples revealing increased IGF-1 expression in a specific $\mathrm{BrCa}$ subtype associated with better prognosis [45]. The contradictory role of circulating and tissue IGF-1 may be partially explained by clinical data showing a lack of correlation between circulating and tissue IGF-1 levels [46].

Several factors could explain this discrepancy. Circulating IGF-1 levels may reflect the IGF-1 expression from several organs/tissues and/or metabolic processes and may thus not correlate with $\mathrm{BrCa}$ status per se. Thus, tissue IGF-1 levels may be a better marker of tumor IGF-1 expression compared to serum levels, as has already been established in mammary gland branching morphogenesis [47]. Within tissue microenvironment, increased IGF-1 levels may reflect cell differentiation into a less aggressive phenotype. Ethnic and other differences among the different groups studied may also account for these conflicting results. Further studies are warranted in order to delineate the importance of circulating (endocrine) versus tissue (autocrine/paracrine) levels of IGF-1 in disease risk and progression. Future investigation should focus on specific ethnic groups, measure IGF-1 levels in both serum and breast tissue of the same patient and correlate those findings with disease risk and outcome factors.

In addition to the above epidemiological findings, many pre-clinical laboratory studies have focused on the impact of IGF-1 in cancer cell proliferation, migration, tumor growth and metastasis using in vitro and in vivo models to identify the signaling pathways involved in these processes. Triple-negative cells (negative for PR, ER and HER2) have shown increased proliferation and survival in response to exogenous IGF-1 via both AKT and MAPK pathways [48]. IGF-1 release from differentiated or precursor adipocytes derived from obese patients was two fold higher compared to lean individuals. It also induced the proliferation of MCF7 cells in co-culture experiments, further supporting the notion that obesity per se could contribute to BrCa progression [49]. Microarray analysis in an ex vivo model of primary breast fibroblasts derived from $\mathrm{BrCa}$ patients revealed a signature of genes associated with proliferation following stimulation with IGF-1 [50]. An earlier study suggested that IGF-1mediated stimulation of proliferation might act through transcriptional regulation [51]. Administration of IGF-1 induces invasion of MDA-MB-231 BrCa cells via the formation of cellular protrusions called lamellipodia, a characteristic projection at the front edge of motile cells believed to function as the motor pulling the cell forward during cell migration [52]. In vivo findings also indicate a tumor-promoting role of IGF-1. MCF-7 cells stably overexpressing IGF-1 induce significantly higher tumor volumes compared with control or mock cells in mouse xenografts [51]. It is also well known that autocrine IGF-1 signaling affects mammary development. Indeed, conditional and epithelial-specific knockout of IGF-1 results in reduced mammary branching during ductal growth [53]. Targeting IGF-1 in mammary epithelium will clarify the role of autocrine IGF-1 signaling in neoplastic 
transformation of breast epithelium. Future studies should focus on this approach.

Recent research efforts have used animal models to delineate the impact of IGF-1 in complex disease events including metabolic regulations, angiogenesis and metastasis. Prenatal administration of IGF-1 in pregnant wild type (WT) mice results in increased body weight, higher breast density with longer ductal elongation and higher breast stem/progenitor cell populations of prepubescent offspring compared to phosphate buffered saline (PBS) controls [54]. Transgenic mice specifically overexpressing IGF-1 in mammary epithelium demonstrate upregulation of the Vascular Endothelial Growth Factor (VEGF), a proangiogenic factor, in prepubertal glands and induction of cyclooxygenase-2 (COX-2), an inflammatory molecule that is also associated with angiogenesis and is responsible for formation of prostaglandin (PG), [55]. It is also well established that caloric restriction prevents mammary tumorigenesis in rodents. Mouse models have indicated that IGF-1 may play a key role in tumor reduction via the AKT/mTOR pathway following caloric restriction [56]. Furthermore, the effect of caloric restriction in IGF-1 levels may regulate luminal tumor growth by modulating the epithelial-mesenchymal transition (EMT) process and chemokine milieu [57]. This pathway appears to be involved in the metastasis of breast tumors. Bone is one of the most common distant target sites for BrCa metastasis. Hiraga et al. showed that bone derived IGF-1 stimulates proliferation and bone localization of breast cancer cells in vivo through activation of $\mathrm{AKT}$ and recruitment of transcription factor NF-kB [58]. The fact that IGF-1 is mostly expressed by stroma underscores the significance of the interplay between stroma and epithelium dururing IGF-1 paracrine signaling resulting in disease establishment and progression. The excess of paracrine IGF-1 signaling via stromal production may trigger epithelial IGF-1 expression, leading to a more malignant phenotype. Within the epithelium, aberrant IGF-1 autocrine signaling could further contribute to disease aggressiveness. Future studies should focus on clarification of the paracrine role of IGF-1, in establishment and progression of breast carcinoma, via in vivo models specifically overexpressing or lacking IGF-1 in stroma. In conclusion, IGF-1 plays a key role in $\mathrm{BrCa}$ development, progression and metastasis. It achieves this through autocrine, paracrine and endocrine interactions between stromal and breast cancer cells within many microenvironments: the primary tumor site, the circulation and/or host tissue and migrating tumor cells at metastatic sites (Figure 1).

\section{IGF-1 binding proteins (IGFBPs) in breast cancer}

A wealth of experiment evidence implicates IGFBPs, in BrCa pathophysiology, particularly $\mathrm{IGFBP}_{2}, \mathrm{IGFBP}_{3}$ and IGFBP $_{5}$. Most studies suggest that elevated systemic or tissue IGFBP levels are found in breast malignancies. The interaction of IGFBPs with $\mathrm{BrCa}$ can be either inhibitory or stimulatory via both IGF-dependent and -independent pathways. Although many studies report a positive association between $\mathrm{BrCa}$ risk and circulating IGFBPs levels (mainly IGFBP $_{3}$ ) calculated from IGF1/ IGFBPs ratios, only a few studies have directly measured free molecules with conflicting results. Among Brazilian women, no association has been detected between serum $\mathrm{IGFBP}_{3}$ and $\mathrm{BrCa}$ risk [23], whereas a pooled data analysis of prospective studies revealed a positive (although non-statistically significant) correlation between $\mathrm{IGFBP}_{3}$ and $\mathrm{BrCa}$ [20]. Furthermore, plasma $\mathrm{IGFBP}_{3}$ levels have been shown to be independent of mammographic density, which is a well-established BrCa risk factor [26,27].

The link between IGFBPs and $\mathrm{BrCa}$ outcome is also unclear. Recent studies did not detect a significant association between plasma $\mathrm{IGFBP}_{3}$ and overall survival or risk of all-cause mortality $[28,29]$. Although other findings indicate that a poor $\mathrm{BrCa}$ outcome may be associated with systemic and tissue IGFBP $_{3}$ [59-61], studies on the correlation between IGFBP $_{2}$ levels and disease prognosis are limited. Hensch et al. reported an association of $\mathrm{IGFBP}_{3}$ with $\mathrm{BrCa}$ variables known to be predictive of outcomes, including tumor grade, body mass index (BMI), ER and premenopausal status. The same study reported a positive association between tissue IGFBP $_{2}$ levels and overall survival, suggesting that protein levels of both IGFBPs in $\mathrm{BrCa}$ are under hormonal and obesity control [62]. In contrast, IGFBP $_{5}$ tumor tissue levels have been found to be significantly associated with poor disease outcome and the addition of $\mathrm{IGFBP}_{4}$ (measured as IGFBP $_{5} /$ IGFBP $_{4}$ ratio expression levels) further increased prognostic power [63].

At the DNA level, the genetic polymorphism $A-202 C$ of $I_{G F B P}$ (SNP, rs2854744) at the promoter region has been extensively studied for potential associations with circulating $\mathrm{IGFBP}_{3}$ levels and $\mathrm{BrCa}$ risk. Multiple studies have reported that the $A-202 C$ genetic variation of $I G F B P_{3}$ is not associated with $\mathrm{BrCa}$ risk among Caucasian, African and Asian women [31,34,38,39], whereas others provide evidence for a correlation between $A-202 C$ polymorphism and increased IGFBP $_{3}$ circulating levels. The postulated correlation is thought to be, due to enhanced promoter activity, indicating a regulation in cis $[40,64]$. Other SNPs of both IGFBP ${ }_{1}$ and IGFBP I $_{3}$ have also been associated with plasma IGFBP $_{3}$ levels $[36,64]$. Additionally, a Mendelian randomization study showed that the a allele of $I_{G F B P}$ SNP rs 2854744 is associated with increased levels of circulating $\mathrm{IGFBP}_{3}$ and decreased BrCa risk [65].

Although the exact mechanism needs to be elucidated, in vitro experiments indicate that $\mathrm{IGFBP}_{3}$ inhibits $\mathrm{BrCa}$ proliferation and induces apoptosis. A recent 




study suggested that $\mathrm{IGFBP}_{3}$ regulates cell cycle by inducing a G1/S phase arrest when overexpressed in MCF7 cells [66]. The role of IGFBP $_{2}$ cell cycle regulation has also been demonstrated. IGFBP $_{2}$ expression has been found to modulate $\beta$-catenin (a key effector of cell cycle regulation) in an IGF-1R dependent manner. It has also been found to be associated with lymph node metastasis in $\mathrm{BrCa}$ cells [67]. In contrast, $\mathrm{IGFBP}_{5}$ induces cellular adhesion and inhibits migration of MCF7 cells via the activation of AKT in an IGF-independent manner, consistent with previous studies suggesting an apoptotic role for IGFBP $_{5}$ in $\mathrm{BrCa}$ [68]. IGFBP 4 may inhibit IGF-1-mediated effects, including tumor promoting ones, through the formation of IGF-1-binding complexes. Like all IGFBPs, IGFBP 4 is sensitive to several proteases. Recombinant IGFBP 4 , capable of IGF-1 binding and resistant to protease cleavage by pregnancy-associated plasma protein-A (PAPP-A), has been shown to block mammary tumor growth and inhibit angiogenesis in a murine BrCa model [69].
IGF-1 receptor (IGF-1R) in breast cancer

IGF-1R mediates the anti-apoptotic and tumorigenic effects of IGF-1 and, as expected, is frequently overexpressed in $\mathrm{BrCa}$. Consequently, several studies have indicated a correlation of IGF-1R expression with disease development $[70,71]$. Women with high cytoplasmic levels of IGF-1R in epithelial cells found in benign terminal duct lobular units (TDLU's) biopsies, have up to 15 times increased $\mathrm{BrCa}$ incidence [72].

Once cancer has been established, the importance of IGF-1R for disease progression remains unclear. Increased IGF-1R levels have been detected in many cases of breast malignancy, most often independently of cancer subtype, ER, PR or HER2 status. Furthermore, many studies indicate a down-regulation of IGF-1R upon cancer progression, whereas others report elevated levels in metastatic stages. Increased tissue IGF-1R mRNA levels strongly correlate with poor patient clinical outcomes across different molecular $\mathrm{BrCa}$ subtypes [73], whereas IGF-1R is highly expressed in patients with early $\mathrm{BrCa}$ and overall 
positively associated with good prognostic variables. IGF-1R may have differential prognostic impact in $\mathrm{BrCa}$ molecular subtypes; IGF-1R has been associated with favorable outcome in patients with the luminal $\mathrm{B} \mathrm{BrCa}$ molecular subtype, in contrast to HER2 enriched patients [74]. Additionally, a positive association between IGF-1R and better clinical outcomes in hormone receptor positive, HER2 negative tumors was recently reported [75], while in another luminal subtype group, IGF-1R mRNA has been significantly correlated with improved BrCa-specific survival (BCSS). The same study found a correlation between IGF-1R protein levels and prolonged BCSS and association between IGF-1R mRNA expression and both relapse-free survival (RFS) and BCSS indicating a concurrence between IGF-1R mRNA and protein levels in primary breast tumors [76].

Several studies have attempted to clarify the relationship between specific genetic variants of $I G F-1 R$ and disease development and progression. Instead of typical functional polymorphisms in the coding region of IGF$1 R$ gene, recent studies aimed to identify novel genetic variants located in untranslated regions (UTRs), such as miRNA's binding sites, that could potentially regulate the expression patterns of IGF-1R. Although a wealth of evidence supports the key role of miRNAs in several tumorigenic processes, only a few studies have evaluated the potential association between polymorphisms in miRNA binding sites and cancers. The specific SNP (rs28674628) is located in a predicted binding site for the miRNA miR-515-5p, which directly regulates IGF-1R levels, in the 3' UTR of the IGF-1R gene as demonstrated by computational analysis. Gilam et al. showed that the rs 28674628 is significantly associated with earlier age of diagnosis and increased BrCa risk among Jewish BRCA1 mutation carriers [77]. The rs2016347 SNP is also located in the 3' UTR of IGF-1R and in silico analysis predicted a functional role through transcriptional regulation and possibly miRNA binding. Indeed, patients carrying the $\mathrm{G}$ allele of the IGF-1R rs 2016347 polymorphism have poorer prognosis compared with those carrying $\mathrm{G} / \mathrm{T}$ or $\mathrm{T} / \mathrm{T}$ and has been associated with increased risk of tumor progression and death [78]. Seven others SNPs located in intron regions of the $I G F-1 R$ gene have been also associated with $\mathrm{BrCa}$ risk in Korean women [79]. Future studies may apply a Mendelian randomization approach to elucidate the association between functional $I G F-1 R$ polymorphisms and BrCa risk.

Propelled by the data accumulated by miRNA approaches, researchers are now focusing on elucidating the molecular mechanisms underlying the gene regulation of $I G F-1 R$. Recent studies have provided new insights into the molecular functions and biological significance of IGF-1R in BrCa by suggesting the role of novel transcription factors and mechanisms implicated in IGF-IR regulation. Regulation of $I G F-1 R$ is mainly achieved at the transcriptional level through transcription factors interfering with the GC-rich "initiator" motif (lacking TATA and CCAAT boxes) of the IGF-1R promoter in either a stimulatory or inhibitory fashion. Previous studies have reported a down regulation of $I G F-1 R$ potentiated by the cognate IGF-1 ligand. Several other molecules have been involved in these processes. These include molecules that normally inhibit $I G F-1 R$ expression such as the tumor suppressor proteins BRCA1, p53, the Wilm's tumor (WT1) and von Hippel-Lindau (VHL), as well as molecules that stimulate IGF-1R production such as Sp1, KLF-6 and ER $\alpha$ [80-86]. Using a novel DNA affinity chromatography, Sarfstein et al. reported a total of $63 I G F-1 R$-promoter binding proteins (mostly nuclear) belonging to previously known or novel transcription factors as well as non-DNA-specific binding proteins involved in major cellular processes, including proliferation, apoptosis, protein synthesis, DNA repair, tumor suppression and oncogenesis. From these proteins, 24 have been shown to bind to the $I G F-1 R$ promoter only in MCF7 cells, whereas 19 only in C4.12.5 cells (ER-negative) and even those that are ubiquitous have been found to be expressed in different levels within these cells. This suggests a distinct $I G F-1 R$ regulation depending on ER status. ChIP assays and coexpression experiments have shown that PARP1, Sp1, c-jun and HMGA1 directly bind to IGF-1R promoter in vivo and c-jun, KLF6 and E2F1 enhance its activity [87]. Of note, two independent groups simultaneously reported in 2010 that IGF-1R undergoes nuclear translocation in human cancers, indicating that IGF-1R itself may act as a transcription factor $[88,89]$. Although IGF-1R lacks a nuclear localization sequence, experiments revealed that SUMOylation events as well as the receptor's kinase activity are responsible for nuclear translocation. Co-localization with RNA-polymerase II and binding to chromatin, as shown by co-precipitation with histone $\mathrm{H} 3$, further support a transcriptional regulation role for IGF-1R $[88,89]$. Subsequently, a relevant novel autoregulation function for IGF-1R was reported [3] revealing that IGF-1R not only translocates to the nucleus but also specifically binds to its own promoter in $\mathrm{ER}^{-} \mathrm{BrCa}$ cells. This enhances the activity of the promoter and thus IGF-1R acts as a transcriptional auto-activator [3]. These results delineate the complex $I G F-1 R$ autoregulation in $\mathrm{BrCa}$ (Figure 2). They have broadened our understanding of the molecular functions of IGF-1R in different disease stages and highlight the potential of IGF-1R targeting in patients with $\mathrm{BrCa}$.

The significance of IGF-IR in $\mathrm{BrCa}$ is further supported by the observation that absent or severely reduced IGF-1R expression leads to non-viable MCF7 cells after a few tissue culture passages [90]. An important 


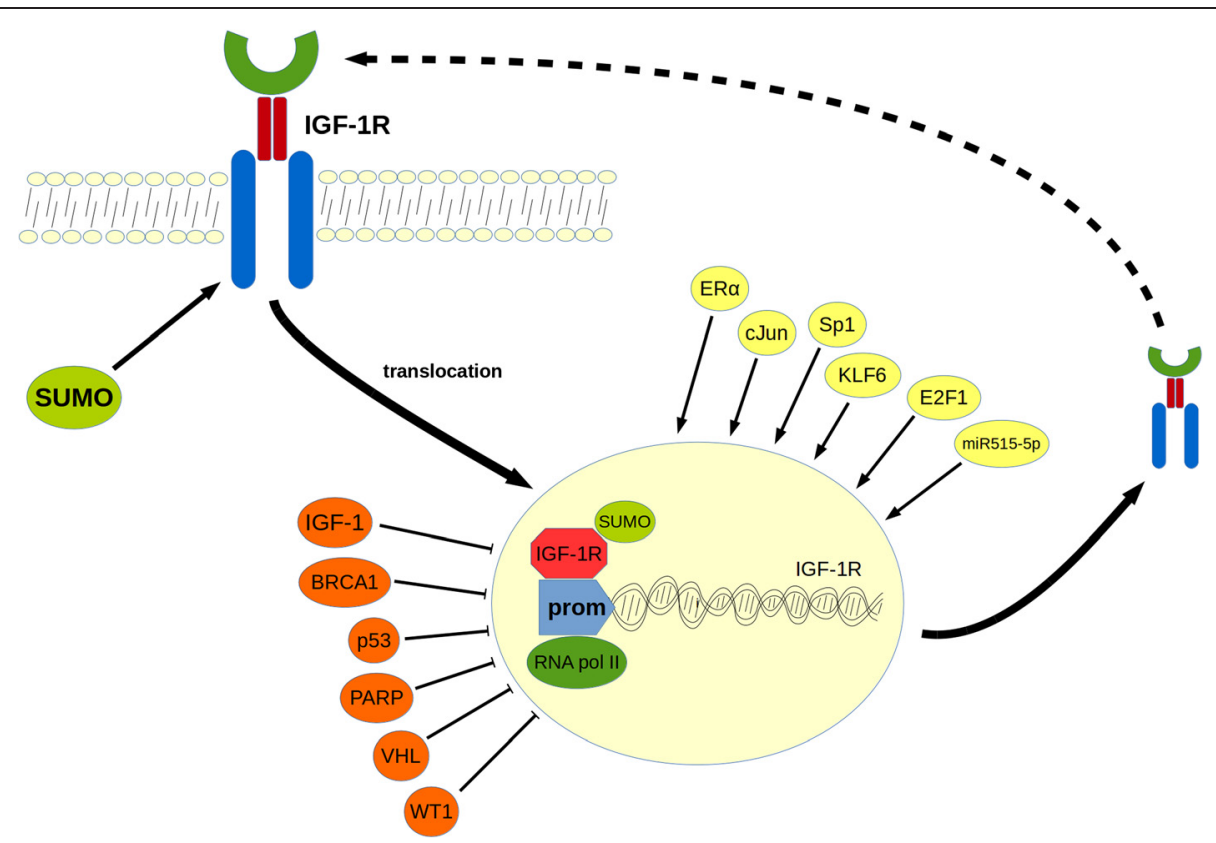

Figure 2 The IGF-1 receptor (auto-) regulation mechanism in breast cancer. SUMOylation of the IGF-1 receptor drives IGF-1R to nuclear translocation. Nuclear IGF-1R upregulates IGF-1R protein levels through direct binding to its own promoter. Other factors could also contribute to IGF-1R transcriptional regulation acting both as enhancers (ERa, miR515-5p and transcription factors c-Jun, Sp1, KLF6, E2F1,) or inhibitors (IGF-1, BRCA1, PARP, tumor suppressors p53, VHL, and transcription factor WT1). SUMO: small ubiquitin-like modifier; ERa: Estrogen receptor a; BRCA1: Breast cancer 1-early onset protein; KLF6: Kruppel-like factor 6; PARP: Poly-ADP ribose polymerase; VHL: von Hippel Lindau protein; WT1: Wilms tumor 1 protein.

area for future research will be to clarify the role of IGF$1 \mathrm{R}$ expression and downstream signaling pathways in different $\mathrm{BrCa}$ molecular subtypes. Whereas basal-like tumors frequently have mutations of p53 gene and therefore induce $I G F-1 R$ transcriptional upregulation, claudin-low subtypes frequently underexpress IGF-1R and closely resemble mammary epithelial stem cells expressing many of the EMT markers. Indeed, studies in transgenic mice reveal that epithelial-specific overexpression of IGF-1R induces mammary tumors with basal-like characteristics whereas epithelial-specific downregulation of IGF-1R produces tumor with a more claudin-low molecular profile [91]. The same team has previously reported that doxycycline-induced downregulation of IGF-1R in mammary epithelium using the same animal model induced tumor regression [92]. Furthermore, mouse xenograft experiments showed increased IGF-1R prosphorylation in $\mathrm{CD} 45^{-} / \mathrm{CD} 24^{-} / \mathrm{CD} 44^{+}$breast cancer stem cell (BCSC), while activation of the PI3K/ AKT/mTOR pathway facilitated BCSC maintenance and increased their EMT phenotype indicating a regulatory role for the IGF-1R pathway in $\mathrm{BrCa}$ stem/progenitor cells [93].

It is well known that IGF-1R shares a high degree of homology with both A and B isoforms of the Insulin receptor (IR) [94]. Binding of insulin to IR leads to similar molecular events as IGF-1R activation including phosphorylation of IRS-1 and consequently activation of both AKT and MAPK. The role of IR and especially IRA as an alternative to IGF-1R signaling in $\mathrm{BrCa}$ is highlighted by studies addressing a regulatory effect of IR in mammary tumorigenesis [95], increased proliferation of $\mathrm{BrCa}$ cells in response to insulin [96] and upregulation of IRA isoforms in breast tumors [97]. Furthermore, IR can form hybrid receptors with IGF-1R: IGF-1R/IRB has higher affinity for IGF-1 whereas IGF-1R/IRA has higher affinity for IGF-2 [98] and is involved in cancer signaling pathways [99]. This relationship delineates the significance of IR and IGF-2 mediated signaling in $\mathrm{BrCa}$ via IGF-1R downstream activation. IRA generally has higher affinity for IGF-2 than IRB. The IGF-2 receptor binds, among other proteins, IGF-2 and is proposed to have tumorsuppressing effects in $\mathrm{BrCa}$ [100]. Alterations in IGF-2R levels due to genetic abnormalities in breast tumors may lead to modulation of $\mathrm{BrCa}$ tumorigenicity possibly via an IGF-1R depended manner [101]. Reduced levels of functional IGF-2R may lead to increased IGF-2-mediated IGF-1R signaling. The significance of IR signaling in physiological processes such as glucose regulation indicates that future research should focus on targeting both IR and IGF-2 alongside with IGF-1R in BrCa therapeutics, in a tissue specific manner. 
Recent studies also indicate that IGR-1R may be used as a molecular target for $\mathrm{BrCa}$ imaging. In a panel comparing other potential imaging targets (EGFR, HER2, GLUT1 and others), IGF-1R was found to be suitable for molecular imaging strategies in $80 \%$ of female and $77 \%$ of male breast tumors [102,103].

\section{Estrogen receptor (ER) and the IGF-1 system in breast cancer} The importance of steroids and especially the ER status in disease progression is well established. Its significance is further supported by the fact that anti-estrogens, such as tamoxifen are routinely used in $\mathrm{BrCa}$ treatment. Crosstalk between growth factors and estrogens may be responsible for the development of estrogen-independent BrCa tumors [104]. Although the exact mechanism is not currently known, it is evident that there is a cross-talk between the IGF-1 system, ER and the cognate ER ligand $17 \beta$-estradiol (E2). BrCa cells have a differential response to IGF-1 with regards to both proliferation and survival depending on their ER status. Specifically, cells expressing both IGF-1R and ER demonstrate synergistic or additive growth effects in response to simultaneous administration of ligands (IGF-1, E2) [105]. Many components of the IGF-1 system are under the transcriptional control of ER/E2. A well-established example of this phenomenon is IGF-1R modulation by ER $\alpha$ as described above. A bidirectional regulation has also been proposed whereby IGF-1 induced pathways regulate ER $\alpha$ - dependent functions and vice versa. The mechanism underlying this cross-talk may be particularly important for the development of combination treatment strategies. Becker et al. demonstrated that the IGF-1/IGF-1R axis induces phosphorylation of ERa through ribosomal S6 kinase 1 (S6K1), a downstream molecule of the PI3K/AKT/ mTOR pathway. Through chromatin and promoter binding, activated ER $\alpha$ modulates both the transcriptional regulation of $\mathrm{ER} \alpha$ induced genes as well as $\mathrm{BrCa}$ cell growth and proliferation [4]. Other recent studies suggest that IGF-1 may be regulated by both ER $\alpha$ and BRCA1. IGF-1 expression has been shown to be activated by estrogens whereas breast tumors with BRCA1 mutations demonstrate elevated IGF-1 levels. Both ER $\alpha$ and BRCA1 can bind to an estrogen-responsive element like site (EREL) in the $I G F-1$ promoter, thus enhancing or suppressing IGF-1 expression respectively [5]. Aromatase is a key enzyme during estrogen biosynthesis and is routinely used as a therapeutic target in ER positive BrCa tumors. Prostaglandin E2 (PGE2) along with HER2 and growth factors enhance aromatase activity via post-transcriptional mechanisms in BrCa cells mediated by the IGF-1/IGF-1R axis through both AKT and MAPK pathways. Thus, IGF-1 pathways can enhance aromatase activity via post-transcriptional modifications that do not affect aromatase protein levels [106]. The two subtypes of ER (ER $\alpha$ and ER $\beta)$ are found in different levels in breast tumors and can produce distinct cellular responses. However, we still lack a detailed understanding of the complex interaction between the ER $\alpha$ and ER $\beta$ subtypes with the IGF-1/IGF-1R axis and E2. MCF7 cells engineered to express reduced levels of IGF$1 \mathrm{R}$ demonstrate decreased proliferation and increased apoptosis in response to E2 compared to controls. The $\mathrm{ER} \alpha / \mathrm{ER} \beta$ ratio is also impaired in these cells. Specifically, ER $\alpha$ is reduced whereas ER $\beta$ is elevated resulting in increased phosphorylation of p38 MAPK and activation of the p53 substrate protein, leading to apoptosis [90]. Other findings also support a cross-talk between E2 and the IGF-1/IGF-1R axis. It has been demonstrated that in vitro $\mathrm{E} 2$ and IGF-1 co-regulate a number of genes comprised mainly of tumor suppressing factors associated with poor disease outcome. E2 can also induce IGF-1R expression in mouse xenograft models $[107,108]$. Furthermore, IGF-1 alone in MCF7, or both IGF-1 and E2, in $\mathrm{BrCa}$ cells overexpressing the IGF-1R, can induce the IGF-1R/ER $\alpha$ association. IGF-1 stimulates activation of $\mathrm{ER} \alpha$, which consequently binds to IGF-1R, inducing downstream phosphorylation of AKT and ERK1/2 leading to increased cell growth via enhanced IGF-1-signaling pathways [109]. Tian et al., demonstrated that the IGF-1/ $E R \alpha$ cross-talk is altered during development, and this may corroborate reports indicating an age-depended association between IGF-1 levels and BrCa risk. They proposed a non-genomic mechanism based in in vivo model study, in which ER $\alpha$ forms a complex with IRS1, triggering PI3K/AKT pathway in the prepubertal stage. This is in contrast to the postpubertal stage, where the reduced ER $\alpha$ levels prevent the ER $\alpha /$ IRS1 complex formation, and alter the signaling via the Raf/MAPK pathway [110]. Additionally, a non-genomic crosstalk between ER $\alpha$ and both Akt and ERK signaling pathways has been reported in obese postmenopausal women [111]. Although the exact mechanism is not clear, estrogens may be modulated by the IGF-1 system via both transcriptional and post-transcriptional mechanisms leading to increased $\mathrm{BrCa}$ proliferation and growth through activation of the IGF-1 signaling pathways (Figure 3).

\section{Interaction between the IGF-1 system and other growth factors in breast cancer}

The IGF-1/IGF-1R axis may interact with other growth factors in the $\mathrm{BrCa}$ milieu. IGF-1 may cross-talk with the transforming growth factor beta-1 (TGF $\beta 1$ ), a molecule known to induce EMT, in BrCa. IGF-1 can activate matrix metalloproteinases through both AKT and MAPK pathways subsequently activating TGF $\beta 1$ leading to nuclear translocation of $\beta$-catenin and EMT [112]. Other studies also contribute to this crosstalk of IGF-1 with b-catenin and the Wnt pathway. Phyllodes tumors 


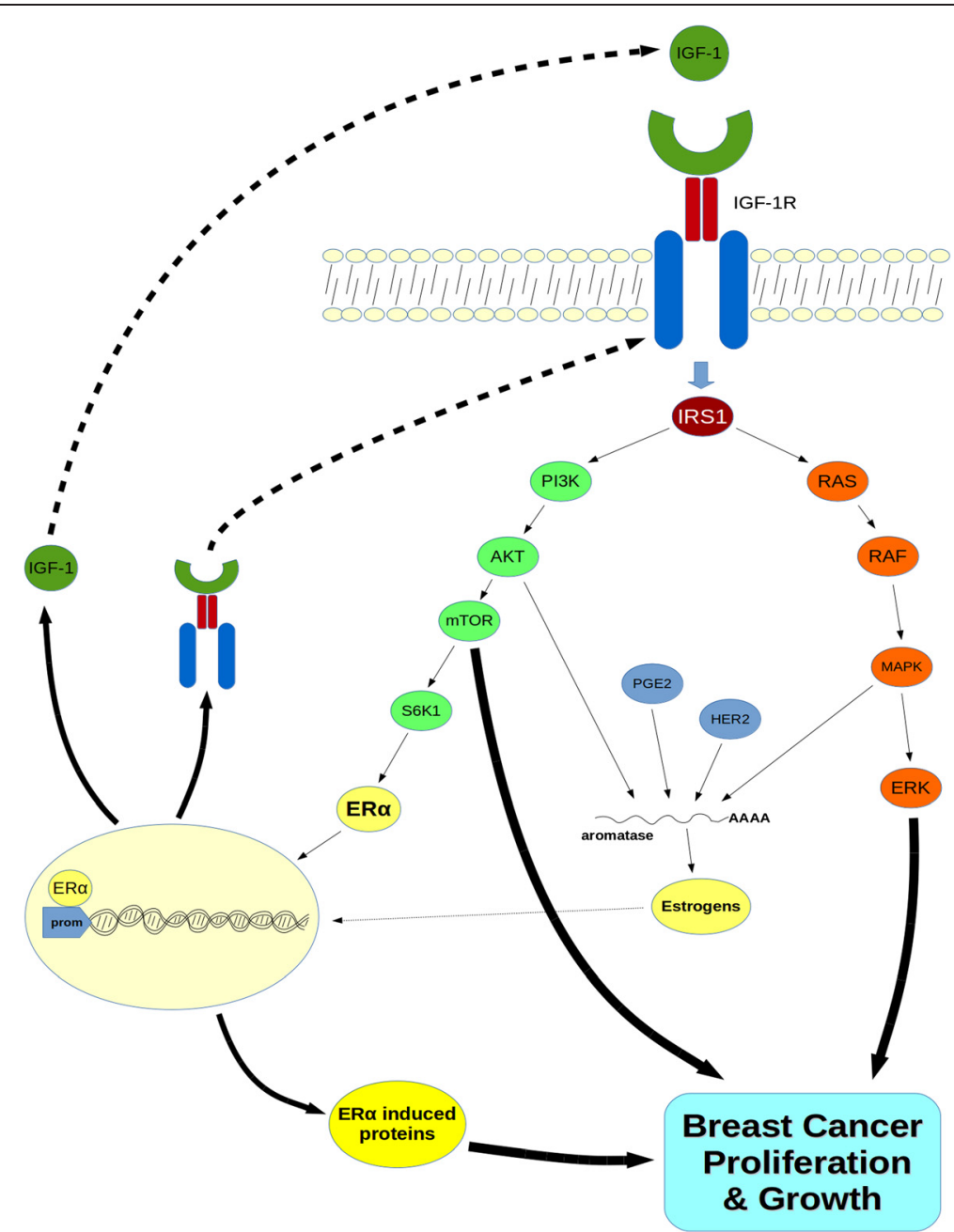

Figure 3 Schematic representation of the crosstalk between the IGF-1 system and estrogens in breast cancer. Binding of IGF-1 to IGF-1R triggers both PI3K/AKT/mTOR and MAPK/ERK signaling pathways, leading to enhanced breast cancer growth and proliferation. S6K1, a downstream molecule of the AKT/mTOR pathway induces phosphorylation of ERa. Activated ERa acts as transcription factor, through direct binding to promoter of target genes, consequently upregulating IGF-1, IGF-1R and other ERa-induced genes which also stimulate breast cancer progression. Prostaglandin E2 (PGE2) along with HER2 and both phosphorylated AKT and MAPK enhance aromatase activity through post-transcriptional mechanisms leading to elevated estrogen levels. Estrogens further contribute to transcriptional regulation of both IGF-1 and IGF-1R, consequently recycling the system's signaling, enhancing growth and proliferation of breast tumors. S6K1: Ribosomal protein S6 kinase 1 protein; mTOR: mammalian target of rapamycin; HER2: human epidermal growth factor receptor 2 protein.

are composed of both stroma and epithelium and are considered to be rare breast malignancies. It has been suggested that IGF-1 alongside with Wnt signaling contributes to the $\beta$-catenin nuclear translocation found in phyllodes tumors [113]. Very recently, Liao et al., showed that IGF-1 induces MUC1 expression, a glycoprotein engaged in multiple cancer-related pathways, via AKT signaling, promoting translocation of $\beta$-catenin and EMT progression in MCF7 cells [114]. Thus, IGF-1, possibly through the involvement of other molecules, cross-talks with the Wnt/ß-catenin pathway, via both $\mathrm{AKT}$ and/or ERK signaling, promoting migration of breast tumors. Other lines of evidence indicate an association with the vascular endothelial growth factor (VEGF)/ VEGFR axis, which comprise of key molecules for angio- and lymphangio- genesis as well as tumor (including breast) progression and metastasis. Morgillo et al., indicate a significant association between high circulating levels of IGF-1, IGFBP ${ }_{3}$ and VEGFc with lymph node metastasis in endocrine-responsive BrCa patients [115]. Both ERK and AKT can contribute in IGF-1 induced upregulation of VEGF-c and may play important roles in lymph node metastasis of $\mathrm{BrCa}$ [116]. Furthermore, both IGF-1R and VEGFR-2 were found in a liquid biopsy assay to be coexpressed in circulating tumor cells (CTCs) [117]. Since $\mathrm{Lu}$ et al. demonstrated that increased IGF-1 levels are 
associated with trastuzumab resistance [118], recent focus has turned into clarifying the cross-talk between the IGF1 system and the Epidermal Growth Factor Receptors (EGFR) family. ERBB2 (HER2) may contribute to decreased IGF-1R expression during mammary tumorigenesis [119]. An association between IGFBP and ERBB2 in IGF-1-dependent tumor transformation has been reported in mammary luminal epithelial cells [120]. Dearth et al., demostrated that ERBB2-induced mammary tumorigenesis is independent of circulating IGF-1 levels, indicating that the IGF-1/HER2 cross-talk may occur via autocrine and paracrine signaling in $\mathrm{BrCa}$ [121]. The IGF-1 system may also interact with components of the extracellular matrix (ECM) affecting tumor growth and progression. Complexes of IGF-1 with IGFBP3 or IGFBP5 and vitronectin (VN) have been shown to induce MCF7 survival and regulation of genes implicated in migration and invasion processes [122].

\section{Targeting the IGF-1R in breast cancer: clinical evidence} Both in vitro and in vivo evidence strongly suggest that the IGF-1 system could serve as a promising target candidate in BrCa therapeutics. Indeed, over the last decade, many strategies targeting several components of the IGF-1 system, have been tested. The majority of these involved targeting the IGF-1R, either with monoclonal antibodies (mAbs) causing internalization of the receptor, or by blocking the receptor's tyrosine kinase domain activation using receptor tyrosine kinase inhibitors (RTKIs). The first recruited $\mathrm{mAb}$ against IGF-1R is CP-751,871 (figitumumab) which has demostrated good pre-clinical antitumor efficacy against several cancers including $\mathrm{BrCa}$ [123]. Only mild toxicities induced by figitumumab have been reported [124]. Figutumumab has also been tested in phase I (NCT00635245 and NCT01536145) and phase II (NCT00372996) clinical trials against $\mathrm{BrCa}$ with apparently negative unpublished results. IMC-A12 (cixutumu$\mathrm{mab}$ ) is another mAb against IGF-1R. It has been tested in a phase I trial in combination with temsirolimus in patients with resistant ER positive breast tumors and only mild toxicities were seen [125]. A phase II trial of cixutumumab is currently ongoing (NCT00699491). Another phase II trial (NCT00684983) is evaluating the effect of cixutumumab in combination with capecitabine and lapanitib in patients with metastatic HER2+ $\mathrm{BrCa}$ [126]. R1507 (RO4858696) is another monoclonal IgG antibody specifically targeting IGF-1R that has demonstrated no dose-limiting toxicities [127]. A phase Ib study showed that R1507 is well tolerated when added to six standard chemotherapy regiments in patients with various solid tumors, including $\mathrm{BrCa}$ [128]. Another phase I trial (NCT00882674) in women with operable breast cancer and a phase II trial (NCT00796107) of R1507 in combination with letrozole in women with advanced breast tumors have finished, with results pending publication. The same mAb has also successfully been used for imaging breast cancer in vivo using either SPECT and/or PET imaging techniques [129]. Unlike most of the mAbs against IGF-1R, figutumumab and SCH717454 have the ability to block signals induced by hybrid receptors $[124,130]$ and this regimen has been tested in a phase II clinical trial (NCT00954512) in patients with advanced solid tumors. The reported adverse events common to most IGF-1R mAbs include anemia, fever, diarrhea, arthralgia, leukopenia, thrombocytopenia, rash, fatigue and anorexia with hyperglycemia being the most common. Noticeable, hyperglycemia was not reported for R1507 [128].

Since the first RTKI (NVP-ADW742) targeting IGF-1R [131], research efforts have focused in developing of these molecules as potential IGF-1R inhibitors. Most of these molecules target the tyrosine domain of both IGF$1 R$ or IR, which may compromise specificity. Although many of these molecules have demonstrated good preclinical results, only a few have actually been translated in ongoing clinical trials, probably due to increased cytotoxicity events. Indeed, production of the NVP-ADW742 was halted due to toxicity issues. OSI-906 (linsitinib), a RTKI targeting both IGF-1R and IR, was investigated as a treatment for hormone sensitive breast cancer in combination with endocrine therapy and erlonitib in a phase II clinical trial (NCT01205685). Unfortunately, this study was terminated as all patients experienced severe toxicities and tumor progression. BMS-754807, another dual RTKI is being tested in a currently ongoing phase II trial (NCT01225172) in combination with letrozole in women with andvanced ER positive, non-steroidal aromatase inhibitor resistant breast tumors [132]. Another phase I/II trial of BMS-754807 in combination with transtuzumab in patients with advanced or metastatic HER2 positive breast tumors has been completed (NCT00788333) and complete results remain to be published. Except specificity another limitation of the RTKI approach is, in contrast to mAbs, the lack of receptor internalization, which means that IGF-1R could retain it's activity a while after inhibition treatment ends. Targeting the IGF-1 system via inhibiting IGF-1R signal transduction cascade presents limitations. The complexity of this system, eliminates the possibilities for efficient targeting. Even if we could specifically block the IGF-1R and not IR, unwanted effects may arise such as glucose dysregulation and diabetes due to the inhibition of hybrid IGF-1R/IR receptors. On the other hand, targeting of hybrid receptors in $\mathrm{BrCa}$ therapeutics, could be desirable as they may act more as IGF$1 \mathrm{R}$ rather than IR. In addition, IGF-1R targeting may not inhibit the IGF-2 mediated signal transduction via IR and/ or hybrid receptors. Further insights into this complex crosstalk, may help us overcome some disappointing 
clinical results and allow the translation of novel molecules and strategies to specifically suppress the IGF-1Rinduced tumor promoting effects.

\section{Conclusions}

A growing body of evidence supports the association of the IGF-1 system with $\mathrm{BrCa}$ establishment and progression. Conflicting results may arise from discordant methodologicals approaches, distinct molecular subtypes studied, genetic differences between different populations and tumor heterogeneity.

The complex IGF-1/IGF-1R axis cascade has received significant attention to date and a wealth of experimental evidence from both in vitro and in vivo models and human studies have implicated the IGF-1 system with $\mathrm{BrCa}$ biology. The prospect of efficiently targeting the IGF-1 system in $\mathrm{BrCa}$ is certainly attractive. Further insight on the molecular mechanisms driving the disease via the IGF-1 system will open new avenues for the diagnosis and treatment of BrCa. Numerous challenges will have to be overcome prior to reaching the goal of IGF-1 regulation for the prevention and management of $\mathrm{BrCa}$. Elucidating the IGF-1 expression patterns and diverse molecular pathways may allow the development of effective diagnostic and treatment strategies against $\mathrm{BrCa}$ that may prove beneficial for selective population subgroups.

\section{Ethical approval}

Reported research carried on humans are in compliance with the Helsinki Declaration, whereas experimental research on animals follow internationally recognized guidelines.

\footnotetext{
Abbreviations

IGF-1: Insulin-like growth factor-1; GFBP ${ }_{1-5}$ : Insulin-like growth factor binding proteins 1-5; BrCa: Breast cancer; GH: Growth hormone; IRS-1: Insulin receptor substrate 1; PI3K: Phosphatidylinositol 3-kinase; MAPK: Mitogen-activated protein kinase; ERa- $\beta$ : Estrogen receptor a- $\beta$; PR: Progesterone receptor; SUMO: Small ubiquitin-like modifier; BRCA1: Breast cancer 1-early onset protein; KLF6: Kruppel-like factor 6; PARP1: Poly-ADP ribose polymerase 1; VHL: Von hippel lindau protein; WT1: Wilms tumor 1 protein; S6K1: Ribosomal protein S6 kinase 1 protein; mTOR: Mammalian target of rapamyci; HER2: Human epidermal growth factor receptor 2 protein; SNP: Single-nucleotide polymorphism; PBS: Phosphate buffer saline; EMT: Epithelial to mesenchymal transition; CTCs: Circulating tumor cells; ECM: Extracellular matrix; BD: Binding domain; VEGFc: Vascular endothelial growth factor receptor c; EGFR: Epidermal growth factor receptor; TGF $\beta$ : Transforming growth factor $\beta$; UTR's: Untranslated regions; EREL: Estrogen-responsive element-like site; PGE2: Prostaglandin E2; ChIP: Chromatin immunoprecipitation; COX-2: Cyclooxygenase-2; VN: Vitronectin; ECR: Evolutionary conserved regions; DFS: Disease-free survival; TDLU's: Terminal duct lobular units; BCSC: Breast cancer stem cell; BCSS: BrCa-specific survival; mAb: Monoclonal antibody; RTKI: Receptor tyrosine kinase inhibitor; IR: Insulin receptor.
}

\section{Competing interests}

The authors declare that they have no competing interests.

\section{Authors' contributions}

PFC: AB, ES, PM: FG, MK: ES, FG. All authors read and approved the final manuscript.

\section{Authors' information}

Christopoulos P.F: M.Sc, Ph. D, Research Fellow at Department of Experimental Physiology, Medical School, National and Kapodistrian University of Athens, Athens, Greece.

Msaouel P: M.D, Ph. D, Chief Medical Resident at Jacobi Medical Center, Department of Internal Medicine, Albert Einstein College of Medicine, Bronx, NY, USA.

Koutsilieris M: M.D, Ph. D, Chairman of the Department of Experimental Physiology, Medical School, National \& Kapodistrian University of Athens, 75 Micras Asias Str., 11527 Goudi-Athens, Greece, Tel.: +30 210-7462597; Fax: +30 210-7462571.

\section{Acknowledgments}

We are grateful to Dr. Jenna Cottral and Maria Balta for their helpful conversations and contributions to conception and drafting of this manuscript. All authors declare that there was no source of funding regarding this manuscript.

\section{Author details}

'Department of Experimental Physiology, Medical School, National and Kapodistrian University of Athens, 75 Mikras Asias Street, 11527 Goudi, Athens, Greece. ${ }^{2}$ Department of Internal Medicine, Jacobi Medical Center, Albert Einstein College of Medicine, Bronx, NY, USA.

Received: 17 July 2014 Accepted: 7 January 2015

Published online: 15 February 2015

\section{References}

1. Ruan W, Kleinberg DL. Insulin-like growth factor I is essential for terminal end bud formation and ductal morphogenesis during mammary development. Endocrinology. 1999;140:5075-81.

2. Deeks S, Richards J, Nandi S. Maintenance of normal rat mammary epithelial cells by insulin and insulin-like growth factor 1. Exp Cell Res. 1988;174:448-60

3. Sarfstein R, Pasmanik-Chor M, Yeheskel A, Edry L, Shomron N, Warman N, et al. Insulin-like Growth Factor-I Receptor (IGF-IR) translocates to nucleus and autoregulates IGF-IR gene expression in breast cancer cells. J Biol Chem. 2012;287:2766-76.

4. Becker MA, Ibrahim YH, Cui X, Lee AV, Yee D. The IGF pathway regulates ERa through a S6K1-dependent mechanism in breast cancer cells. Mol Endocrinol. 2011;25:516-28.

5. Kang HJ, Yi YW, Kim HJ, Hong YB, Seong YS, Bae I. BRCA1 negatively regulates IGF-1 expression through an estrogen-responsive element-like site. Cell Death Dis. 2012;3:e336.

6. Denley A, Cosgrove L, Booker GW, Wallace JC, Forbes BE. Molecular interactions of the IGF system. Cytokine Growth Factor Rev. 2005;16:421-39.

7. Philippou A, Maridaki M, Pneumaticos S, Koutsilieris M. The complexity of the IGF1 gene splicing, post-translational modification and bioactivity. Mol Med Camb Mass. 2014;20:202-14.

8. Macias H, Hinck L. Mammary gland development. Wiley Interdiscip Rev Dev Biol. 2012;1:533-57.

9. Yu H, Rohan T. Role of the insulin-like growth factor family in cancer development and progression. J Natl Cancer Inst. 2000;92:1472-89.

10. Gennigens C, Menetrier-Caux C, Droz JP. Insulin-Like Growth Factor (IGF) family and prostate cancer. Crit Rev Oncol Hematol. 2006;58:124-45.

11. Philippou A, Halapas A, Maridaki M, Koutsilieris M. Type I insulin-like growth factor receptor signaling in skeletal muscle regeneration and hypertrophy. J Musculoskelet Neuronal Interact. 2007;7:208-18.

12. Lee AV, Jackson JG, Gooch JL, Hilsenbeck SG, Coronado-Heinsohn E, Osborne CK, et al. Enhancement of insulin-like growth factor signaling in human breast cancer: estrogen regulation of insulin receptor substrate-1 expression in vitro and in vivo. Mol Endocrinol Baltim Md. 1999;13:787-96.

13. LeRoith $D$, Roberts $C T$. The insulin-like growth factor system and cancer. Cancer Lett. 2003;195:127-37.

14. Pollak M. Insulin and insulin-like growth factor signalling in neoplasia. Nat Rev Cancer. 2008;8:915-28.

15. Perou CM, Sørlie T, Eisen MB, van de Rijn M, Jeffrey SS, Rees CA, et al. Molecular portraits of human breast tumours. Nature. 2000;406:747-52

16. Sachdev D, Yee D. The IGF system and breast cancer. Endocr Relat Cancer. 2001;8:197-209. 
17. Peyrat J-P, Bonneterre J, Beuscart R, Djiane J, Demaille A. Insulin-like growth factor 1 receptors in human breast cancer and their relation to estradiol and progesterone receptors. Cancer Res. 1988;48:6429-33.

18. Maor S, Yosepovich A, Papa MZ, Yarden RI, Mayer D, Friedman E, et al. Elevated insulin-like growth factor-I receptor (IGF-IR) levels in primary breast tumors associated with BRCA1 mutations. Cancer Lett. 2007;257:236-43.

19. Peyrat JP, Bonneterre J, Hecquet B, Vennin P, Louchez MM, Fournier C, et al. Plasma insulin-like growth factor-1 (IGF-1) concentrations in human breast cancer. Eur J Cancer Oxf Engl 1990. 1993;29A:492-7.

20. Endogenous Hormones and Breast Cancer Collaborative Group, Key TJ, Appleby PN, Reeves GK, Roddam AW. Insulin-like growth factor 1 (IGF1), IGF binding protein 3 (IGFBP3), and breast cancer risk: pooled individual data analysis of 17 prospective studies. Lancet Oncol. 2010;11:530-42.

21. Kaaks R, Johnson T, Tikk K, Sookthai D, Tjønneland A, Roswall N, et al. Insulin-like growth factor I and risk of breast cancer by age and hormone receptor status-A prospective study within the EPIC cohort. Int J Cancer. 2014;134(11):2683-90.

22. Pasanisi P, Bruno E, Venturelli E, Manoukian S, Barile M, Peissel B, et al. Serum levels of IGF-I and BRCA penetrance: a case control study in breast cancer families. Fam Cancer. 2011;10:521-8.

23. Trinconi AF, Filassi JR, Soares-Júnior JM, Baracat EC. Evaluation of the insulin-like growth factors (IGF) IGF-I and IGF binding protein 3 in patients at high risk for breast cancer. Fertil Steril. 2011;95:2753-5.

24. Toriola AT, Lundin E, Schock H, Grankvist K, Pukkala E, Chen T, et al. Circulating Insulin-like Growth Factor-l in pregnancy and maternal risk of breast cancer. Cancer Epidemiol Biomarkers Prev. 2011;20:1798-801.

25. Diorio C, Pollak M, Byrne C, Mâsse B, Hébert-Croteau N, Yaffe M, et al. Insulin-like growth factor-I, IGF-binding protein-3, and mammographic breast density. Cancer Epidemiol Biomark Prev Publ Am Assoc Cancer Res Cosponsored Am Soc Prev Oncol. 2005;14:1065-73.

26. Rice MS, Tworoger SS, Rosner BA, Pollak MN, Hankinson SE, Tamimi RM. Insulin-like growth factor-1, insulin-like growth factor-binding protein-3, growth hormone, and mammographic density in the Nurses' Health Studies. Breast Cancer Res Treat. 2012;136:805-12.

27. Rinaldi S, Biessy C, Hernandez M, Lesueur F, dos Santos Silva I, Rice MS, et al. Circulating concentrations of insulin-like growth factor-l, insulin-like growth factor-binding protein-3, genetic polymorphisms and mammographic density in premenopausal Mexican women: Results from the ESMaestras cohort: IGF-I, IGFBP-3 and mammographic density in women. Int J Cancer. 2014:134:1436-44

28. Hartog H, Boezen HM, de Jong MM, Schaapveld M, Wesseling J, van der Graaf WTA. Prognostic value of insulin-like growth factor 1 and insulin-like growth factor binding protein 3 blood levels in breast cancer. Breast. 2013;22:1155-60.

29. Duggan C, Wang C-Y, Neuhouser ML, Xiao L, Smith AW, Reding KW, et al. Associations of insulin-like growth factor and insulin-like growth factor binding protein-3 with mortality in women with breast cancer. Int J Cancer. 2013;132:1191-200.

30. Al-Ajmi K, Ganguly SS, Al-Ajmi A, Mandhari ZA, Al-Moundhri MS. Insulin-like growth factor 1 gene polymorphism and breast cancer risk among Arab Omani women: a case-control study. Breast Cancer (Auckl). 2012;6:103-12.

31. Sarkissyan M, Mishra DK, Wu Y, Shang X, Sarkissyan S, Vadgama JV. IGF gene polymorphisms and breast cancer in African-American and Hispanic women. Int J Oncol. 2011;38:1663-73.

32. Huang Q, Wang C, Qiu L-J, Shao F, Yu J-H. The association between IGF1 CA repeat polymorphisms and breast cancer risk: a meta-analysis. Breast Cancer Res Treat. 2011;129:191-4.

33. He B, Xu Y, Pan Y, Li R, Gao T, Song G, et al. Differential effects of insulin-like growth factor-1 CA repeat polymorphism on breast cancer risk along with race: a meta-analysis. Gene. 2013;525:92-8.

34. Quan H, Tang H, Fang L, Bi J, Liu Y, Li H. IGF1 (CA)19 and IGFBP-3-202A/C gene polymorphism and cancer risk: a meta-analysis. Cell Biochem Biophys. 2014;69:169-78.

35. Javadi M, Hematti S, Tavassoli M. Polymorphic CA repeat length in insulin-like growth factor 1 and risk of breast cancer in Iranian women. Med Oncol. 2012;29:516-20.

36. Biong M, Gram IT, Brill I, Johansen F, Solvang HK, Alnaes GIG, et al. Genotypes and haplotypes in the insulin-like growth factors, their receptors and binding proteins in relation to plasma metabolic levels and mammographic density. BMC Med Genomics. 2010:3:9.
37. Henningson M, Hietala M, Törngren T, Olsson H, Jernström H. IGF1 htSNPs in relation to IGF-1 levels in young women from high-risk breast cancer families: implications for early-onset breast cancer. Fam Cancer. 2011;10:173-85.

38. Qian B, Zheng H, Yu H, Chen K. Genotypes and phenotypes of IGF-I and IGFBP-3 in breast tumors among Chinese women. Breast Cancer Res Treat. 2011;130:217-26

39. Canzian F, Cox DG, Setiawan WW, Stram DO, Ziegler RG, Dossus L, et al. Comprehensive analysis of common genetic variation in 61 genes related to steroid hormone and insulin-like growth factor-I metabolism and breast cancer risk in the $\mathrm{NCl}$ breast and prostate cancer cohort consortium. Hum Mol Genet. 2010;19:3873-84.

40. Gu F, Schumacher FR, Canzian F, Allen NE, Albanes D, Berg CD, et al. Eighteen insulin-like growth factor pathway genes, circulating levels of IGF-I and its binding protein, and risk of prostate and breast cancer. Cancer Epidemiol Biomark Prev Publ Am Assoc Cancer Res Cosponsored Am Soc Prev Oncol. 2010;19:2877-87.

41. Yaren A, Turgut S, Ayada C, Akcilar R, Degirmencioglu S, Gokoz Dogu G. Insulin-like growth factor I (lgf-1) gene polymorphism in patients with nonmetastatic breast cancer. Gene. 2012;503:244-7.

42. Muendlein A, Lang AH, Geller-Rhomberg S, Winder T, Gasser K, Drexel H, et al. Association of a common genetic variant of the IGF-1 gene with event-free survival in patients with HER2-positive breast cancer. J Cancer Res Clin Oncol. 2013;139:491-8.

43. Lindström S, Thompson DJ, Paterson AD, Li J, Gierach GL, Scott C, et al. Genome-wide association study identifies multiple loci associated with both mammographic density and breast cancer risk. Nat Commun. 2014;5:5303.

44. Chong KYM, Subramanian A, Mokbel K, Sharma AK. The prognostic significance of the insulin-like growth factor-1 ligand and receptor expression in breast cancer tissue. J Surg Oncol. 2011;104:228-35.

45. Mu L, Tuck D, Katsaros D, Lu L, Schulz V, Perincheri S, et al. Favorable outcome associated with an IGF-1 ligand signature in breast cancer. Breast Cancer Res Treat. 2012;133:321-31.

46. Llanos AA, Brasky TM, Dumitrescu RG, Marian C, Makambi KH, Kallakury BVS, et al. Plasma IGF-1 and IGFBP-3 may be imprecise surrogates for breast concentrations: an analysis of healthy women. Breast Cancer Res Treat. 2013;138:571-9.

47. Richards RG, Klotz DM, Walker MP, Diaugustine RP. Mammary gland branching morphogenesis is diminished in mice with a deficiency of insulin-like growth factor-I (IGF-I), but not in mice with a liver-specific deletion of IGF-I. Endocrinology. 2004;145:3106-10.

48. Davison Z, de Blacquière GE, Westley BR, May FE. Insulin-like growth factor-dependent proliferation and survival of triple-negative breast cancer cells: implications for therapy. Neoplasia N Y NY. 2011;13:504.

49. D'Esposito V, Passaretti F, Hammarstedt A, Liguoro D, Terracciano D, Molea $\mathrm{G}$, et al. Adipocyte-released insulin-like growth factor-1 is regulated by glucose and fatty acids and controls breast cancer cell growth in vitro. Diabetologia. 2012:55:2811-22.

50. Rajski M, Zanetti-Dällenbach R, Vogel B, Herrmann R, Rochlitz C, Buess M. IGF-I induced genes in stromal fibroblasts predict the clinical outcome of breast and lung cancer patients. BMC Med. 2010;8:1.

51. Pacher M, Seewald MJ, Mikula M, Oehler S, Mogg M, Vinatzer U, et al. Impact of constitutive IGF1/IGF2 stimulation on the transcriptional program of human breast cancer cells. Carcinogenesis. 2007;28:49-59.

52. Morimura S, Takahashi K. Racl and Stathmin but not EB1 are required for invasion of breast cancer cells in response to IGF-I. Int J Cell Biol. 2011;2011:1-9.

53. Loladze AV, Stull MA, Rowzee AM, Demarco J, Lantry JH, Rosen CJ, et al. Epithelial-specific and stage-specific functions of insulin-like growth factor-I during postnatal mammary development. Endocrinology. 2006;147:5412-23.

54. Chang C-I, Low HP, Qiu L, Strohsnitter WC, Hsieh C-C. Prenatal modulation of breast density and breast stem cells by insulin-like growth factor-1. Am J Stem Cells. 2012;1:239.

55. Tian J, Lambertz I, Berton TR, Rundhaug JE, Kiguchi K, Shirley SH, et al. Transgenic insulin-like growth factor-1 stimulates activation of COX-2 signaling in mammary glands. Mol Carcinog. 2012;51:973-83.

56. Dogan S, Johannsen A, Grande J, Cleary M. Effects of intermittent and chronic calorie restriction on mammalian target of rapamycin (mTOR) and IGF-I signaling pathways in mammary fat pad tissues and mammary tumors. Nutr Cancer. 2011;63:389-401. 
57. Ford NA, Nunez NP, Holcomb VB, Hursting SD. IGF1 dependence of dietary energy balance effects on murine Met1 mammary tumor progression, epithelial-to-mesenchymal transition, and chemokine expression. Endocr Relat Cancer. 2013;20:39-51.

58. Hiraga T, Myoui A, Hashimoto N, Sasaki A, Hata K, Morita Y, et al. Bone-derived IGF mediates crosstalk between bone and breast cancer cells in bony metastases. Cancer Res. 2012;72:4238-49.

59. Vestey SB, Perks CM, Sen C, Calder CJ, Holly JMP, Winters ZE. Immunohistochemical expression of insulin-like growth factor binding protein-3 in invasive breast cancers and ductal carcinoma in situ: implications for clinicopathology and patient outcome. Breast Cancer Res BCR. 2005;7:R119-29.

60. Rocha RL, Hilsenbeck SG, Jackson JG, Lee AV, Figueroa JA, Yee D. Correlation of insulin-like growth factor-binding protein-3 messenger RNA with protein expression in primary breast cancer tissues: detection of higher levels in tumors with poor prognostic features. J Natl Cancer Inst. 1996;88:601-6.

61. Yu H, Levesque MA, Khosravi MJ, Papanastasiou-Diamandi A, Clark GM, Diamandis EP. Insulin-like growth factor-binding protein-3 and breast cancer survival. Int J Cancer J Int Cancer. 1998;79:624-8.

62. Probst-Hensch NM, Steiner JHB, Schraml P, Varga Z, Zürrer-Härdi U, Storz M, et al. IGFBP2 and IGFBP3 protein expressions in human breast cancer: association with hormonal factors and obesity. Clin Cancer Res Off J Am Assoc Cancer Res. 2010;16:1025-32.

63. Becker MA, Hou X, Harrington SC, Weroha SJ, Gonzalez SE, Jacob KA, et al. IGFBP ratio confers resistance to IGF targeting and correlates with increased invasion and poor outcome in breast tumors. Clin Cancer Res. 2012;18:1808-17

64. Rosendahl AH, Hietala M, Henningson M, Olsson H, Jernström H. IGFBP1 and IGFBP3 polymorphisms predict circulating IGFBP-3 levels among women from high-risk breast cancer families. Breast Cancer Res Treat. 2011;127:785-94.

65. Al-Zahrani A, Sandhu MS, Luben RN, Thompson D, Baynes C, Pooley KA, et al. IGF1 and IGFBP3 tagging polymorphisms are associated with circulating levels of IGF1, IGFBP3 and risk of breast cancer. Hum Mol Genet. 2006;15:1-10.

66. Wu C, Liu X, Wang Y, Tian H, Xie Y, Li Q, et al. Insulin-like factor binding protein-3 promotes the $\mathrm{G} 1$ cell cycle arrest in several cancer cell lines. Gene. 2013;512:127-33.

67. Sehgal P, Kumar N, Kumar VRP, Patil S, Bhattacharya A, Kumar MV, et al. Regulation of protumorigenic pathways by Insulin like growth factor binding protein2 and its association along with $\beta$-catenin in breast cancer lymph node metastasis. Mol Cancer. 2013;12:63.

68. Sureshbabu A, Okajima H, Yamanaka D, Tonner E, Shastri S, Maycock J, et al. IGFBP5 induces cell adhesion, increases cell survival and inhibits cell migration in MCF-7 human breast cancer cells. J Cell Sci. 2012;125:1693-705.

69. Ryan AJ, Napoletano S, Fitzpatrick PA, Currid CA, O'Sullivan NC, Harmey JH. Expression of a protease-resistant insulin-like growth factor-binding protein-4 inhibits tumour growth in a murine model of breast cancer. $\mathrm{Br}$ J Cancer. 2009;101:278-86.

70. Papa V, Gliozzo B, Clark GM, McGuire WL, Moore D, Fujita-Yamaguchi Y, et al. Insulin-like growth factor-I receptors are overexpressed and predict a low risk in human breast cancer. Cancer Res. 1993;53:3736-40.

71. Jones RA, Campbell Cl, Gunther EJ, Chodosh LA, Petrik JJ, Khokha R, et al. Transgenic overexpression of IGF-IR disrupts mammary ductal morphogenesis and induces tumor formation. Oncogene. 2007;26:1636-44.

72. Tamimi RM, Colditz GA, Wang Y, Collins LC, Hu R, Rosner B, et al. Expression of IGF1R in normal breast tissue and subsequent risk of breast cancer. Breast Cancer Res Treat. 2011;128:243-50.

73. Peiró G, Adrover E, Sánchez-Tejada L, Lerma E, Planelles M, Sánchez-Payá J, et al. Increased insulin-like growth factor-1 receptor mRNA expression predicts poor survival in immunophenotypes of early breast carcinoma. Mod Pathol. 2011;24:201-8

74. Yerushalmi R, Gelmon KA, Leung S, Gao D, Cheang M, Pollak M, et al. Insulin-like growth factor receptor (IGF-1R) in breast cancer subtypes. Breast Cancer Res Treat. 2012;132:131-42.

75. Mountzios G, Aivazi D, Kostopoulos I, Kourea HP, Kouvatseas G, Timotheadou $E$, et al. Differential expression of the insulin-like growth factor receptor among early breast cancer subtypes. PLoS One. 2014;9:e91407.

76. Fu P, Ibusuki M, Yamamoto Y, Hayashi M, Murakami K, Zheng S, et al. Insulin-like growth factor-1 receptor gene expression is associated with survival in breast cancer: a comprehensive analysis of gene copy number, mRNA and protein expression. Breast Cancer Res Treat. 2011;130:307-17.
77. Gilam A, Edry L, Mamluk-Morag E, Bar-Ilan D, Avivi C, Golan D, et al. Involvement of IGF-1R regulation by miR-515-5p modifies breast cancer risk among BRCA1 carriers. Breast Cancer Res Treat. 2013;138:753-60.

78. Winder T, Giamas G, Wilson PM, Zhang W, Yang D, Bohanes P, et al. Insulin-like growth factor receptor polymorphism defines clinical outcome in estrogen receptor-positive breast cancer patients treated with tamoxifen. Pharmacogenomics J. 2014;14:28-34.

79. Kang H-S, Ahn SH, Mishra SK, Hong K-M, Lee ES, Shin KH, et al. Association of polymorphisms and haplotypes in the insulin-like growth factor 1 receptor (IGF1R) gene with the risk of breast cancer in Korean women. PLOS ONE. 2014;9:e84532.

80. Werner H, Re GG, Drummond IA, Sukhatme VP, Rauscher FJ, Sens DA, et al. Increased expression of the insulin-like growth factor I receptor gene, IGF1R, in Wilms tumor is correlated with modulation of IGF1R promoter activity by the WT1 Wilms tumor gene product. Proc Natl Acad Sci U S A. 1993;90:5828-32.

81. Beitner-Johnson D, Werner H, Roberts CT, LeRoith D. Regulation of insulin-like growth factor I receptor gene expression by Sp1: physical and functional interactions of Sp1 at GC boxes and at a CT element. Mol Endocrinol Baltim Md. 1995;9:1147-56.

82. Abramovitch S, Glaser T, Ouchi T, Werner H. BRCA1-Sp1 interactions in transcriptional regulation of the IGF-IR gene. FEBS Lett. 2003;541:149-54.

83. Rubinstein M, Idelman G, Plymate SR, Narla G, Friedman SL, Werner H. Transcriptional activation of the insulin-like growth factor I receptor gene by the Kruppel-like factor 6 (KLF6) tumor suppressor protein: potential interactions between KLF6 and p53. Endocrinology. 2004;145:3769-77.

84. Nahor I, Abramovitch S, Engeland K, Werner H. The p53-family members p63 and p73 inhibit insulin-like growth factor-I receptor gene expression in colon cancer cells. Growth Horm IGF Res Off J Growth Horm Res Soc Int IGF Res Soc. 2005;15:388-96.

85. Maor S, Mayer D, Yarden Rl, Lee AV, Sarfstein R, Werner H, et al. Estrogen receptor regulates insulin-like growth factor-I receptor gene expression in breast tumor cells: involvement of transcription factor Sp1. J Endocrinol. 2006;191:605-12

86. Yuen JSP, Cockman ME, Sullivan M, Protheroe A, Turner GDH, Roberts IS, et al. The VHL tumor suppressor inhibits expression of the IGF1R and its loss induces IGF1R upregulation in human clear cell renal carcinoma. Oncogene. 2007;26:6499-508.

87. Sarfstein R, Belfiore A, Werner H. Identification of Insulin-Like Growth Factor-I Receptor (IGF-IR) Gene Promoter-Binding Proteins in Estrogen Receptor (ER)-Positive and ER-Depleted Breast Cancer Cells. Cancers. 2010;2:233-61.

88. Aleksic T, Chitnis MM, Perestenko OV, Gao S, Thomas PH, Turner GD, et al. Type 1 insulin-like growth factor receptor translocates to the nucleus of human tumor cells. Cancer Res. 2010;70:6412-9.

89. Sehat B, Tofigh A, Lin Y, Trocmé E, Liljedahl U, Lagergren J, et al. SUMOylation mediates the nuclear translocation and signaling of the IGFreceptor. Sci Signal. 2010;3:ra10.

90. Mendoza RA, Enriquez MI, Mejia SM, Moody EE, Thordarson G. Interactions between IGF-I, estrogen receptor- (ER ), and ER in regulating growth/apoptosis of MCF-7 human breast cancer cells. J Endocrinol. 2011;208:1-9.

91. Franks SE, Campbell Cl, Barnett EF, Siwicky MD, Livingstone J, Cory S, et al. Transgenic IGF-IR overexpression induces mammary tumors with basal-like characteristics, whereas IGF-IR-independent mammary tumors express a claudin-low gene signature. Oncogene. 2012;31:3298-309.

92. Jones RA, Campbell Cl, Wood GA, Petrik JJ, Moorehead RA. Reversibility and recurrence of IGF-IR-induced mammary tumors. Oncogene. 2009;28:2152-62

93. Chang W-W, Lin R-J, Yu J, Chang W-Y, Fu C-H, Lai AC-Y, et al. The expression and significance of insulin-like growth factor-1 receptor and its pathway on breast cancer stem/progenitors. Breast Cancer Res. 2013;15:R39.

94. De Meyts P, Wallach B, Christoffersen CT, Ursø B, Grønskov K, Latus LJ, et al. The insulin-like growth factor-I receptor. Structure, ligand-binding mechanism and signal transduction. Horm Res. 1994;42:152-69.

95. Papa V, Belfiore A. Insulin receptors in breast cancer: biological and clinical role. J Endocrinol Invest. 1996;19:324-33.

96. Osborne CK, Bolan G, Monaco ME, Lippman ME. Hormone responsive human breast cancer in long-term tissue culture: effect of insulin. Proc Nat Acad Sci U S A. 1976;73:4536-40.

97. Frasca F, Pandini G, Scalia P, Sciacca L, Mineo R, Costantino A, et al. Insulin receptor isoform $A$, a newly recognized, high-affinity insulin-like growth factor II receptor in fetal and cancer cells. Mol Cell Biol. 1999;19:3278-88. 
98. Frasca F, Pandini G, Vigneri R, Goldfine ID. Insulin and hybrid insulin/IGF receptors are major regulators of breast cancer cells. Breast Dis. 2003;17:73-89.

99. Pandini G, Frasca F, Mineo R, Sciacca L, Vigneri R, Belfiore A. Insulin/insulin-like growth factor I hybrid receptors have different biological characteristics depending on the insulin receptor isoform involved. J Biol Chem. 2002;277:39684-95.

100. Ellis MJ, Leav BA, Yang Z, Rasmussen A, Pearce A, Zweibel JA, et al. Affinity for the insulin-like growth factor-II (IGF-II) receptor inhibits autocrine IGF-II activity in MCF-7 breast cancer cells. Mol Endocrinol Baltim Md. 1996;10:286-97.

101. Lee JS, Weiss J, Martin JL, Scott CD. Increased expression of the mannose 6-phosphate/insulin-like growth factor-II receptor in breast cancer cells alters tumorigenic properties in vitro and in vivo. Int J Cancer J Int Cancer. 2003;107:564-70

102. Vermeulen JF, van Brussel AS, van der Groep P, Morsink FH, Bult P, van der Wall $E$, et al. Immunophenotyping invasive breast cancer: paving the road for molecular imaging. BMC Cancer. 2012;12:240.

103. Vermeulen JF, Kornegoor R, van der Wall E, van der Groep P, van Diest PJ. Differential expression of growth factor receptors and membrane-bound tumor markers for imaging in male and female breast cancer. PLoS One. 2013;8:e53353.

104. Gee JM, Robertson JF, Gutteridge E, Ellis IO, Pinder SE, Rubini M, et al. Epidermal growth factor receptor/HER2/insulin-like growth factor receptor signalling and oestrogen receptor activity in clinical breast cancer. Endocr Relat Cancer. 2005;12 Suppl 1:S99-111.

105. Karey KP, Sirbasku DA. Differential responsiveness of human breast cancer cell lines MCF-7 and T47D to growth factors and 17 beta-estradiol. Cancer Res. 1988:48:4083-92.

106. Su B, Wong C, Hong Y, Chen S. Growth factor signaling enhances aromatase activity of breast cancer cells via post-transcriptional mechanisms. J Steroid Biochem Mol Biol. 2011;123:101-8.

107. Casa AJ, Potter AS, Malik S, Lazard Z, Kuiatse I, Kim H-T, et al. Estrogen and insulin-like growth factor-I (IGF-I) independently down-regulate critical repressors of breast cancer growth. Breast Cancer Res Treat. 2012;132:61-73.

108. Heskamp S, Boerman OC, Molkenboer-Kuenen JDM, Koornstra RHT, Linn SC, Oyen WJG, et al. Dynamics of IGF-1R expression during endocrine breast cancer treatment. Mol Imaging Biol. 2014;16:529-37.

109. Yu Z, Gao W, Jiang E, Lu F, Zhang L, Shi Z, et al. Interaction between IGF-IR and ER Induced by E2 and IGF-I. PLoS ONE. 2013;8:e62642.

110. Tian J, Berton TR, Shirley SH, Lambertz I, Gimenez-Conti IB, DiGiovanni J, et al. Developmental stage determines estrogen receptor alpha expression and non-genomic mechanisms that control IGF-1 signaling and mammary proliferation in mice. J Clin Invest. 2012;122:192-204.

111. Bowers LW, Cavazos DA, Maximo IXF, Brenner AJ, Hursting SD, deGraffenried LA. Obesity enhances nongenomic estrogen receptor crosstalk with the PI3K/Akt and MAPK pathways to promote in vitro measures of breast cancer progression. Breast Cancer Res. 2013;15:R59.

112. Walsh LA, Damjanovski S. IGF-1 increases invasive potential of MCF 7 breast cancer cells and induces activation of latent TGF- $\beta 1$ resulting in epithelial to mesenchymal transition. Cell Commun Signal CCS. 2011;9:10.

113. Sawyer EJ, Hanby AM, Poulsom R, Jeffery R, Gillett CE, Ellis IO, et al. Beta-catenin abnormalities and associated insulin-like growth factor overexpression are important in phyllodes tumours and fibroadenomas of the breast. J Pathol. 2003;200:627-32

114. Liao G, Wang M, Ou Y, Zhao Y. IGF-1-induced epithelial-mesenchymal transition in MCF-7 cells is mediated by MUC1. Cell Signal. 2014;26:2131-7.

115. Morgillo F, De Vita F, Antoniol G, Orditura M, Auriemma PP, Diadema MR, et al. Serum insulin-like growth factor 1 correlates with the risk of nodal metastasis in endocrine-positive breast cancer. Curr Oncol. 2013;20:283.

116. Zhu C, Qi X, Chen Y, Sun B, Dai Y, Gu Y. PI3K/Akt and MAPK/ERK1/2 signaling pathways are involved in IGF-1-induced VEGF-C upregulation in breast cancer. J Cancer Res Clin Oncol. 2011;137:1587-94.

117. Pizon M, Zimon DS, Pachmann U, Pachmann K. Insulin-Like Growth Factor Receptor I (IGF-IR) and Vascular Endothelial Growth Factor Receptor 2 (VEGFR-2) are expressed on the circulating epithelial tumor cells of breast cancer patients. PLoS One. 2013;8:e56836.

118. Lu Y, Zi X, Zhao Y, Mascarenhas D, Pollak M. Insulin-like growth factorreceptor signaling and resistance to trastuzumab (Herceptin). J Natl Cancer Inst. 2001;93:1852-7.
119. Campbell Cl, Petrik JJ, Moorehead RA. ErbB2 enhances mammary tumorigenesis, oncogene-independent recurrence and metastasis in a model of IGF-IR-mediated mammary tumorigenesis. Mol Cancer. 2010;9:235.

120. Worthington J, Bertani M, Chan H-L, Gerrits B, Timms JF. Transcriptional profiling of ErbB signalling in mammary luminal epithelial cells-interplay of ErbB and IGF1 signalling through IGFBP3 regulation. BMC Cancer. 2010;10:490.

121. Dearth RK, Kuiatse I, Wang Y-F, Liao L, Hilsenbeck SG, Brown PH, et al. A moderate elevation of circulating levels of IGF-I does not alter ErbB2 induced mammary tumorigenesis. BMC Cancer. 2011;11:377.

122. Kashyap AS, Hollier BG, Manton KJ, Satyamoorthy K, Leavesley DI, Upton Z. Insulin-like growth factor-l: vitronectin complex-induced changes in gene expression effect breast cell survival and migration. Endocrinology. 2011;152:1388-401

123. Cohen BD, Baker DA, Soderstrom C, Tkalcevic G, Rossi AM, Miller PE, et al. Combination therapy enhances the inhibition of tumor growth with the fully human anti-type 1 insulin-like growth factor receptor monoclonal antibody CP-751,871. Clin Cancer Res Off J Am Assoc Cancer Res. 2005; 11:2063-73.

124. Gualberto A. Figitumumab (CP-751,871) for cancer therapy. Expert Opin Biol Ther. 2010;10:575-85.

125. Ma CX, Suman VJ, Goetz M, Haluska P, Moynihan T, Nanda R, et al. A phase I trial of the IGF-1R antibody Cixutumumab in combination with temsirolimus in patients with metastatic breast cancer. Breast Cancer Res Treat. 2013;139:145-53.

126. Haluska P, Reinholz MM, Dueck AC, Linden HM, Lingle WL, Bernath AM, et al. N0733. Phase II trial of capecitabine and lapatinib plus or minus cixutumumab in HER2-positive breast cancer. J Clin Oncol. 2010;28:15s (suppl; abstr TPS129).

127. Kurzrock R, Patnaik A, Aisner J, Warren T, Leong S, Benjamin R, et al. A phase I study of weekly R1507, a human monoclonal antibody insulin-like growth factor-I receptor antagonist, in patients with advanced solid tumors. Clin Cancer Res Off J Am Assoc Cancer Res. 2010;16:2458-65.

128. Mahadevan D, Sutton GR, Arteta-Bulos R, Bowden CJ, Miller PJE, Swart RE, et al. Phase $1 \mathrm{~b}$ study of safety, tolerability and efficacy of R1507, a monoclonal antibody to IGF-1R in combination with multiple standard oncology regimens in patients with advanced solid malignancies. Cancer Chemother Pharmacol. 2014;73:467-73.

129. Heskamp S, van Laarhoven HWM, Molkenboer-Kuenen JDM, Franssen GM, Versleijen-Jonkers YMH, Oyen WJG, et al. ImmunoSPECT and immunoPET of IGF-1R expression with the radiolabeled antibody R1507 in a triple-negative breast cancer model. J Nucl Med Off Publ Soc Nucl Med. 2010;51:1565-72.

130. Bid HK, Zhan J, Phelps DA, Kurmasheva RT, Houghton PJ. Potent inhibition of angiogenesis by the IGF-1 receptor-targeting antibody SCH717454 is reversed by IGF-2. Mol Cancer Ther. 2012;11:649-59.

131. Mitsiades CS, Mitsiades NS, McMullan CJ, Poulaki V, Shringarpure R, Akiyama $M$, et al. Inhibition of the insulin-like growth factor receptor-1 tyrosine kinase activity as a therapeutic strategy for multiple myeloma, other hematologic malignancies, and solid tumors. Cancer Cell. 2004;5:221-30.

132. Haluska P, Dhar A, Hou X, Huang F, Nuyten DSA, Park J, et al. Phase II trial of the dual IGF-1R/IR inhibitor BMS-754807 with or without letrozole in aromatase inhibitor-resistant breast cancer. J Clin Oncol. 2011;29:2011. suppl; abstr TPS111.

\section{Submit your next manuscript to BioMed Central and take full advantage of:}

- Convenient online submission

- Thorough peer review

- No space constraints or color figure charges

- Immediate publication on acceptance

- Inclusion in PubMed, CAS, Scopus and Google Scholar

- Research which is freely available for redistribution 